\title{
PEMANFAATAN AIR DANAU SEBAGAI SUMBER AIR UNTUK IRIGASI
}

\author{
Agung Pamudjianto ${ }^{1)}$, Wilis Sutiono ${ }^{2)}$ \\ 1) Program Studi Teknik Sipil Universitas Muhammadiyah Sorong \\ Jln. Pendidikan No 27 Kota Sorong \\ Emaill : agungumsorong1980@gmail.com
}

\begin{abstract}
Abstrak
Dalam pengelolaan danau mempunyai fungsi utama adalah untuk menstabilkan aliran air, dan di lain sisi danau juga mempunyai fungsi ekonomi yang sangat tinggi, yaitu untuk penyediaan air bersih, baik untuk minum,irigasi, dan industri, juga untuk perikanan budidaya maupun perikanan tangkap. Jika dikelola dengan benar, maka danau akan berfungsi secara optimal sebagai penyangga kehidupan. Penjagaan kuantitas dan kualitas air danau diharapkan dapat menjamin ketersediaan air baku sepanjang daerah alirannya. Masalah yang dihadapi dalam pengelolaan danau adalah pada bagaimana analisa potensi ketersediaan dan pemanfaatan air danau sebagai sumber air irigasi. Yang kedua bagaimana perubahan pola pemanfaatan ruang I tata guna lahan di kawasan hulu danau dalam kaitannya dengan besarnya debit inflow danau. Yang ketiga bahwa sebagaian besar dari danau belum diketahui volumenya dengan pasti, demikian juga halnya dengan tingkat presipitasi, evaporasinya serta debit inflow dan outflow-nya. Dengan demikian pola pemanfaatan bagi berbagai keperluan seperti untuk pemenuhan air irigasi juga belum bisa diprogramkan secara optimal. Dan dari beberapa hasil penelitian disebutkan bahwa beberapa danau mengalami masalah antara lain terjadi sedimentasi, (berkurangnya kedalaman), berkurangnya volume, dan berkurangnya luas cathment areanya, sehingga berpengaruh juga terhadap ketersediaan air untuk supplai air irigasi misalnya. Danau dengan potensi yang dimilikinya, dapat dikembangkan dan dikelola untuk berbagai kepentingan seperti khususnya untuk kepentingan pemenuhan kebutuhan irigasi Meningkatnya permintaan untuk pemenuhan kebutuhan air bersih dari danau/waduk/ situ seperti untuk kebutuhan irigasi, tidak diimbangi dengan konsistensi ataupun upaya peningkatan kapasitas tampungan danau. Hal ini disebabkan adanya perubahan tata guna laha di kawasan tangkapan air danau, pendangkalan danau, dan kerusakan kawasan konservasi danau. Sehingga hal ini mempengaruhi pola pemenuhan kebutuhan air bersih bagi semua kepentingan seperti untuk pemenuhan kebutuhan air irigasi. Pemerintah secara penuh sebenarnya sudah membuat peraturan untuk memback-up pola optimalisasi dan pengelolaan danau untuk kepentingan irigasi, yaitu dengan adanya PP No 20 tahun 2006 tentang irigasi dan UU No 7 tahun 2004 tentang Sumber Daya Air. Akan tetapi dalam tahap implementasinya memang masih perlu kebijakan-kebijakan yang berpihak kepada petani pengguna air irigasi.
\end{abstract}

Keyword : air danau, irigasi, optimalisasi 


\section{PENDAHULUAAN}

\section{A. Definisi Danau}

Beberapa definisi yang bisa diambil diantaranya yaitu :

1. Danau/situ/embung/waduk adalah salah satu sumber air tawar yang menunjang kehidupan semua makhluk hidup dan kegiatan social ekonomi manusia

2. Danau adalah suatu wadah alam yang dapat menahan kelebihan air pada masa aliran air tinggi untuk digunakan pada masa kekeringan.

3. Danau adalah badan air yang dikelilingi daratan dan tertutup / tergenang air atau mengalir secara tetap atau sementara. Danau/ situ digolongkan ke dalam lahan basah alami bersama hutan mangrove,rawa gambut, rawa air tawar, padang lamun, dan terumbu karang. Perairan danau cenderung diam, karena itu dinamakan pula perairan lentik, lawan dari perairan lotik atau mengalir (sungai).

Pada umumnya kedalaman danau bervariasi antara 50 - $200 \mathrm{~m}$, akan tetapi banyak juga yang mempunyai kedalaman lebih rendah dari $50 \mathrm{~m}$.

Di Indonesia terdapat kurang lebih danau kategori besar $>50$ ha sebanyak 500 buah. Danau tersebut tersebar merata di setiap pulau besar (Sumatra, Jawa, Kalimantan Sulawesi, Papua) kecuali Pulau Bali. Sebaliknya waduk besar sebagian besar berlokasi di P.Jawa. Selain kategori danau besar terdapat juga danau kecil yang jumlahnya ribuan dan waduk kecil yang disebut embung. Danau kecil sering dikenal sebagai situ berukuran besar. Di Provinsi Jawa Barat terdapat 354 buah situ, di Provinsi Jawa Timur 438 buah situ.

Danau yang terbesar adalah Danau Toba yang terletak 905 meter dpl, panjang $275 \mathrm{~km}$, lebar $150 \mathrm{~km}$ dengan luas $1.130 \mathrm{~km} 2$, dan kedalaman maksimum $529 \mathrm{~m}$ di bagian utara dan 429 $m$ di bagian selatan. Danau Toba merupakan danau terdalam kesembilan di dunia dan merupakan danau tipe vulkanik kaldera yang terbesar di dunia. Danau yang terdalam di Indonesia adalah danau Montana di Sulawesi Tengah dengan kedalaman maksimum $590 \mathrm{~m}$ dan merupakan danau terdalam ketujuh di dunia.

\section{B. Fungsi Danau}

Dalam pengelolaannya danau mempunyai fungsi utama adalah untuk menstabilkan aliran air, dan di lain sisi danau juga mempunyai fungsi ekonomi yang sangat tinggi, yaitu untuk penyediaan air bersih, baik untuk minum,irigasi, dan industri, juga untuk perikanan budidaya maupun perikanan tangkap. Jika dikelola dengan benar, maka danau akan berfungsi secara optimal sebagai penyangga kehidupan. Penjagaan kuantitas dan kualitas air danau diharapkan dapat menjamin ketersediaan air baku sepanjang daerah alirannya.

Permintaan persediaan air bersih untuk keperluan-keperluan di atas akan terus meningkat seiring meningkatnya populasi jumlah penduduk Indonesia. Diprediksi sampai tahun 2015, permintaan air bersih untuk sektor pertanian (air irigasi) akan meningkat 6,67 \% setiap tahunnya, sedangkan untuk keperluan domestik 6,7 \% dan untuk keperluan industri $12,5 \%$.

\section{PERMASALAHAN}

Masalah yang dihadapi dalam pengelolaan danau adalah pada :

1. bagaimana analisa potensi ketersediaan dan pemanfaatan air danau sebagai sumber air irigasi

2. bagaimana perubahan pola pemanfaatan ruang / tata guna lahan di kawasan hulu danau dalam kaitannya dengan besarnya debit inflow danau

3. sebagaian besar dari danau belum diketahui volumenya dengan pasti, demikian juga halnya dengan tingkat presipitasi, evaporasinya serta debit inflow dan outflownya. Dengan demikian pola pemanfaatan bagi berbagai keperluan seperti untuk pemenuhan air irigasi juga belum bisa diprogramkan secara optimal. 
4. Dari beberapa hasil penelitian disebutkan bahwa beberapa danau mengalami masalah antara lain terjadi sedimentasi, (berkurangnya kedalaman), berkurangnya volume, dan berkurangnya luas cathment areanya, sehingga berpengaruh juga terhadap ketersediaan air untuk supplai air irigasi misalnya.

\section{PEMBAHASAN}

\subsection{Analisa Potensi Ketersediaan dan Pemanfaatan Air Danau sebagai Sumber Air Irigasi.}

Analisa ini sangat diperlukan sebagai data acuan untuk pola pengelolaan dari Sumber Daya Air yang optimal dan efisien yang dapat menghasilkan keuntungan secara umum dan khususnya bagi masyarakat sekitar danau tersebut, misalnya untuk pemenuhan kebutuhan air irigasi para petani. Tahap ini difokuskan dengan menganalisa potensi suatu danau dari segi kuantitasnya apabla ditinjau dari ketersediaan data curah hujannya.

Metode yang dipakai dalam analisa ini adalah sebagai berikut :

- Pengumpulan data., yaitu data primer dan sekunder. Data primer diperoleh dengan cara pengamatan langsung di lapangan, sedangkan data sekunder diperoleh dari instansi terkait.

Data yang dibutuhkan antara lain peta topografi, data curah hujan, data klimatologi, peta daerah cathment area danau, data sungai di sekitar atau di sekililing danau, dan data outflow danau tersebut.

- Metode analisa hidrologi,yaitu :

a. Analisa curah hujan rata-rata dengan metode polygon thiesen

b. Analisa Evapotranspirasi dengan menggunakan data klimatologi untuk mengetahui evapotranspirasi potensial dengan menggunakan metode Penman.

c. Analisa ketersediaan air danau dengan metode FJ. Mock untuk mengetahui besarnya debit inflow atau debit yang masuk ke dalam danau yang berasal dari curh hujan yang dipengaruhi oleh factor klimatologi dan kondisi daerah tangkapannya.

d. Analisa ketersediaan air danau dengan metode rasional, yaitu dengan mengalikan antara kapasitas tampung danau dengan koefisien run off dan intensitas hujan.

Pemanfaatan sumber air untuk keperluan irigasi adalah untuk mengairi sawah-sawah yang berada di wilayah cakupan rencana daerah irigasi danau tersebut.

\subsection{Analisa Pengaruh Perubahan Pola Pemanfaatan Ruang/Tata Guna Lahan di Kawasan Daerah Tangkapan Air (DTA) Danau Terhadap Debit Inflow Danau}

Analisa ini dilakukan dengan melakukan observasi terhadap pola pemanfaatan ruang daratan di kawasan daerah tangkapan air (DTA) danau dengan melakukan pengukuran terhadap (1) luas daratan pada kawasan hutan lindung, dan (2) luas daratan pada kawasan budidaya lahan panen, permukiman dan ladang.

Analisis data dilakukan dengan metode overlay (tumpang tindih) yang diaplikasikan untuk menganalisa perubahan luas lahan pada kawasan lindung dan budidaya menggunakan data dasar peta Rupa Bumi daerah studi dari Bakosurtanal dan dibandingkan dengan data hasil pengukuran langsung dan atau dibandingkan juga dengan peta tata guna lahan yang dibuat pada tahun yang berbeda dengan peta rupa bumi dari Bakosurtanal.

Setelah diketahui perbedaanya,lalu dihitung debit inflownya baik dengan data luas dari tata guna lahan yang lama dan dari data luas hasil pengukuran yang baru,sehingga kita dapat mengetahui seberapa besar perubahan debit inflow yang terjadi.

Sehinggga dalam hal ini dapat dikatakan bahwa penurunan luas penutupan vegetasi akibat perubahan pola pemanfaatan ruang di kawasan daerah tangkapan air (DTA) suatu danau 
diperkirakan merupakan penyebab penurunan kemampuan penyediaan air oleh danau tersebut. Penurunan penutupan vegetasi ini menyebabkan berkurangnya luas areal genangan (di sekitar danau), luas danau, serta kedalaman air danau. Beberapa factor yang diduga mengakibatkan penurunan areal penutupan vegetasi adalah adanya perambahan hutan oleh penduduk untuk pembukaan lahan produksi, pembangunan permukiman dan lain sebagainya.

\subsection{Optimalisasi Program Pemenuhan Kebutuhan Air Irigasi}

Menurut PP No 20 Tahun 2006 tentang Irigasi bab II disebutkan bahwa pemenuhan kebutuhan air irigasi dapat dilaksanakan dengan Pengembangan dan Pengelolaan Sistem Irigasi, dimana langkah pencapaiannya adalah sebagai berikut :

- Pelaksanaannya dibawah tanggungjawab pemerintah, baik pemerintah pusat, provinsi, atau pemerintah kabupaten / kota dan melibatkan semua pihak yang berkepntingan dengan mengutamakan kepentingan dan perta masyarakat petani

- Dilakukan dengan mendayagunakan sumber daya air yang didasarkan pada keterkaitan antara pengelolaan air hujan, air permukaan dan air tanah secara terpadu

- Prinsip yang digunakan adalah prinsip satu sistem irigasi, satu kesatuan pengembangan dan pengelolaannya

\subsection{Pola Pengelolan Danau Dan Waduk}

Sesuai dengan UU. No. 7 Tahun 2004 tentang SumberDaya Air, yang terdiri 3 komponen utama yaitu konservasi, pemanfaatan dan pengendalian daya rusak air. Waduk embung, situ dan danau yang merupakan sumber daya air telah banyak banyak mengalami penurunan fungsi dan kerusakan ekosistem. Hal ini disebabkan oleh karena pengelolan waduk/danau yang banyak mengalami kendala. Dalam UU-Sumber Daya Air telah mengamanatkan untuk melakukan pengelolaan waduk dengan melakukan konservasi, pemanfaatan, pengendalian daya rusak air. Selain itu masih ada peraturan lain seperti PP. No. 51 Tahun 1997, tentang Lingkungan Hidup; PP. No. 82 Tahun 2001, tentang Pengelolaan Kualitas Air dan Pengendalian Pencemaran Air; PP No. 32 Tahun 1990 tentang Kawasan Lindung; Kep. Pres No.123/2001, tentang koordinasi Pengelolaan Sumber Daya Air pada tingkat Propinsi, Wilayah Sungai, Kabupaten dan Kota serta Keputusan Menteri yang terkait tentang pengelolaan sumber daya air.

\section{KESIMPULAN}

1. Danau dengan potensi yang dimilikinya, dapat dikembangkan dan dikelola untuk berbagai kepentingan seperti khususnya untuk kepentingan pemenuhan kebutuhan irigasi

2. Meningkatnya permintaan untuk pemenuhan kebutuhan air bersih dari danau/waduk/ situ seperti untuk kebutuhan irigasi, tidak diimbangi dengan konsistensi ataupun upaya peningkatan kapasitas tampungan danau. Hal ini disebabkan adanya perubahan tata guna laha di kawasan tangkapan air danau, pendangkalan danau, dan kerusakan kawasan konservasi danau. Sehingga hal ini mempengaruhi pola pemenuhan kebutuhan air bersih bagi semua kepentingan seperti untuk pemenuhan kebutuhan air irigasi.

3. Pemerintah secara penuh sebenarnya sudah membuat peraturan untuk memback-up pola optimalisasi dan pengelolaan danau untuk kepentingan irigasi, yaitu dengan adanya PP No 20 tahun 2006 tentang irigasi dan UU No 7 tahun 2004 tentang Sumber Daya Air. Akan tetapi dalam tahap implementasinya memang masih perlu kebijakan-kebijakan yang berpihak kepada petani pengguna air irigasi. 


\section{DAFTAR PUSTAKA}

1. Numar, Afrizal.2004. Analisa Ketersediaan Air Danau Maninjau Ditinjau Dari Data Curah Hujan..

2. A.Kamurur,Veronica,1998. Kondisi Pemanfaatan Ruang Daratan di Kawasan Sekitar Danau Mooat,Kab. Bolaang Mongondaw, Sulut Periode Tahun 1987-1998 .

3. Suhardi.2003. Perubahan Penutupan Lahan Dan Pengaruhnya Terhadap Cadangan Air Pada Daerah Tangkapan Air Danau Dusun Besar.

4. Puslitbang SDA,2004. Pengelolaan Danau dan Waduk Di Indonesia

5. Agus,Fahmuddin,__,Pengelolaan Daerah Tangkapan Air (DTA) Danau dan Dampak Hidrologinya.

6. Pemerintah Republik Indonesia, 2006. Peraturan Pemerintah (PP) No 20 Tahun 2006 tentang Irigasi 